\title{
Effect of Biofertilization in Increasing the Efficiency of Two Peanut Varieties in Utilizing of Phosphorus Fertilization: 1- Effect on Growth
}

\author{
Abdel-Haliem, S. M. ; M. H. Abdel-Motaleb ${ }^{*}$; G. M. Yakout ${ }^{*}$; A. M. Abdel-Wahab ${ }^{*}$ and A. A. Nasef \\ *Agronomy Department, Faculty of Agriculture, Suez Canal University \\ ${ }^{* *}$ Oil Crop Section, Agricultural Research Center, Ismailia, Egypt
}

Received: $24 / 10 / 2015$

\begin{abstract}
Two field experiments were conducted during 2012 and 2013 seasons in the Experimental Farm of Agriculture Research Station, Agric. Res. Centre at Ismailia, Egypt to study the effect of four levels of phosphatic fertilizer i.e. $0,15.5,23.25$ and $31.0 \mathrm{~kg} \mathrm{P}_{2} \mathrm{O}_{5} /$ fad (faddan $=4200 \mathrm{~m}^{2}$ ) combined or separate with applying the biofertilizers phosphorine or microbin on different growth characters and leaf chlorophyll content of two Peanut varieties Giza-6 as erect cv and Gereogry as spread cv. Giza-6 surpassed significantly Gereogry in leaf area/plant, LAI, dry weight of leaves and dry weight of stem and branches, while Gereogry surpassed significantly Giza- 6 in plant height, leaf chlorophyll content, number and dry weight of pods/plant and total dry weight of plant. That was held true at different stages of growth i.e. 70, 85 and 100 days from sowing. Increasing phosphorus fertilizer up to the highest level $31.0 \mathrm{~kg} \mathrm{P} \mathrm{O}_{5} /$ fad with and without biofertilizers phosphorine or microbin increased significantly all the aforementioned growth traits at different stages of growth. It is worthy to note that biofertilizers phosphorine or microbin increased the efficiency of peanut plants in utilizing phosphatic fertilizers, which in turn had favorable effect on peanut growth, consequently increased the different growth characteristics at different growth stages and the two biofertilizers almost did not differ significantly in this respect.
\end{abstract}

Keywords: Biofertilization, phosphorein, microbein, growth, peanut.

\section{INTRODUCTION}

Peanut is the main summer oil crop in Egypt and acreages 134146 fads. $70 \%$ of these areas are new reclaimed soils, mainly sandy soils. So, intensive research work should be carried out on the crop under new reclaimed sandy soil conditions to obtain strong peanut plants in their growth and to increase dry matter accumulation in the vegetative organ. Vegetative organ is the source of photosynthesizes formation which translocation to the sink (seeds), consequently increase peanut crop productivity. In this respect high yielding varieties and fertilization (mineral, especially, phosphorus fertilization and biofertilization) are with great importance. The growth of peanut plants as well as other legumes was found to be affected by phosphorus nutrition (Abdel-Wahab et al., 1999 and Hafiz, 2007).

Phosphorus is constituent of nucleic acids (DNA and RNA) and high energy storage compounds, stimulates cell division and metabolic processes such as photosynthesis and synthesis of protein, carbohydrates and lipids (Marschner, 1986). Also, phosphorus enhances root growth (Russel, 1973), nodulation and N fixation (Albert, 1978). The phosphorus content in the sandy soils is low, in addition Egyptian soils $\mathrm{pH}$ is high. Under such conditions most of the phosphorus content is converted to unavailable form, mainly as tricalcium phosphate. In such case, application of phosphate dissolving bacteria could increase the available phosphorus for plant and increased the efficiency of peanut plants in utilizing phosphatic fertilizer. Many investigators reported that the aforementioned cultural practices i.e. high yielding varieties as well as phosphorus and biofertilization increased growth and growth characteristics of peanut (Madny, 1998; Migawer and Soliman, 2001; Yasein, 2005; Mohamed, 2010 concerning peanut varieties and Kabesh et al., 1987; Bahr, 1997; Detroja et al., 1997; Abdel-Wahab et al., 1999; El-Dsouky and Attia, 1999; Borse et al., 2002; More et al., 2002; El-Habbasha et al., 2005 and Mirvat et al., 2006, concerning phosphorus and biofertilization).

So, the objective of this study was to investigate the response of growth and different growth characters of two peanut varieties to phosphorus and biofertilization in new reclaimed sandy soils.

\section{MATERIALS AND METHODS}

Two field experiments were conducted during 2012 and 2013 seasons in the Experimental Farm of the Agricultural Research Station, Agric. Res. Center at Ismailia, Egypt to study the effect of phosphatic and biofertilization on different growth characteristics and leaf chlorophyll content of two peanut varieties Giza-6 as erect $\mathrm{cv}$ and Gereogry as spread cv. Chemical analysis and physical properties of the experimental sites are stated in Table (1). These analyses were carried out using standard methods described by Piper (1950) and Jackson (1967).

Each experiment consisted of 24 treatments which were the combination of two peanut varieties (Giza-6 and Gereogry) and four levels of phosphatic fertilization $\left(0,100,150,200 \mathrm{~kg} /\right.$ fad (faddan $\left.=4200 \mathrm{~m}^{2}\right)$ in form of calcium superphosphate $\left(15.5 \% \mathrm{P}_{2} \mathrm{O}_{5}\right)$, i.e. $0,15.5$, 23.25 and $31 \mathrm{~kg} \mathrm{P}_{2} \mathrm{O}_{5} / \mathrm{fad}$, combined or not combined with applying biofertilizers phosphorine (contains Bacillus megatherium) or microbin (contains Azotobacter spp., Azospirillum spp., Pseudomonas spp., Bacillus megatherium and Rhizobium spp.). The factorial experiment in split plot design with three replications was made in use, where peanut cvs were allocated in the main plots and $\mathrm{P}_{2} \mathrm{O}_{5}$ levels with and without phosphorine or microbine in the sub plots. Each experimental sub plot consisted of 6 ridges $4 \mathrm{~m}$ in length and $60 \mathrm{~cm}$ in width $\left(4 * 3.6=14.4 \mathrm{~m}^{2}\right)$. 
Table (1): Some physical and chemical properties of the experimental soil in the two seasons of investigation (2012 and 2013).

\begin{tabular}{|c|c|c|}
\hline Properties & $\begin{array}{c}\text { First season } \\
2012\end{array}$ & $\begin{array}{c}\text { Second } \\
\text { season } 2013\end{array}$ \\
\hline \multicolumn{3}{|l|}{ Physical analysis: } \\
\hline Coarse sand $(\%)$ & 74.60 & 72.50 \\
\hline Fine sand (\%) & 18.50 & 18.65 \\
\hline Silt (\%) & 2.45 & 3.50 \\
\hline Clay $(\%)$ & 4.45 & 5.35 \\
\hline Texture grade & Sandy & Sandy \\
\hline \multicolumn{3}{|l|}{ Chemical properties: } \\
\hline $\mathrm{pH}$ & 7.86 & 7.90 \\
\hline $\mathrm{EC} \mathrm{dsm}^{-1}$ & 0.125 & 0.13 \\
\hline OM \% & 0.42 & 0.53 \\
\hline $\mathrm{Ca} \mathrm{CO} 3 \%$ & 1.95 & 2.13 \\
\hline \multicolumn{3}{|l|}{$\begin{array}{l}\text { Soluble cations } \\
\text { meq/100 g soil }\end{array}$} \\
\hline $\mathrm{Ca}^{2+}$ & 0.20 & 0.40 \\
\hline $\mathrm{Mg}^{2+}$ & 0.10 & 0.30 \\
\hline $\mathrm{Na}^{+}$ & 0.22 & 0.58 \\
\hline $\mathrm{K}^{+}$ & 0.10 & 0.13 \\
\hline \multicolumn{3}{|l|}{$\begin{array}{l}\text { Soluble anions } \\
\text { meq/100 g soil }\end{array}$} \\
\hline $\mathrm{CO}_{3}{ }^{2-}$ & - & - \\
\hline $\mathrm{HCO}_{3}^{-}$ & 0.25 & 0.63 \\
\hline $\mathrm{Cl}-$ & 0.22 & 0.68 \\
\hline $\mathrm{SO}_{4}^{2-}$ & 0.15 & 0.30 \\
\hline \multicolumn{3}{|l|}{$\begin{array}{l}\text { Available NPK } \\
\text { (ppm) }\end{array}$} \\
\hline $\mathrm{N}$ & 18.21 & 21.32 \\
\hline $\mathrm{P}$ & 4.85 & 5.78 \\
\hline $\mathrm{K}$ & 63.45 & 73.20 \\
\hline
\end{tabular}

Phosphatic fertilizer at the mentioned rates as well as a basal dose of $15 \mathrm{~kg} \mathrm{~N} /$ fad and $24 \mathrm{~kg} \mathrm{~K}_{2} \mathrm{O} /$ fad for all experiments were applied to the soil during preparing the land. All seeds of peanutcvsGiza- 6 and Gereogry were coated by arab gum and inoculated with the specific Rhizobium strain. Then the seeds were sown by hand on one side of the ridge in hills $10 \mathrm{~cm}$ apart for Giza- 6 and $20 \mathrm{~cm}$ apart for Gereogry on $20^{\text {th }}$ May in the first season 2012 and on $25^{\text {th }}$ May in the second season 2013 and the preceding crop was Egyptian clover in the two growing seasons. The biofertilizers (phosphorine or microbin) was mixed with moisten sand and drilled beside seedlings after 5 days from sowing. After 20 days from sowing peanut plants were thinned to one plant per hill, then the other cultural practices of growing peanut at Ismailia Governorate were followed as normal.

At 70, 85 and 100 days from sowing five guarded plants were taken randomly from the inner ridges in each sub plot for measuring different vegetative growth characters, namely plant height, leaf area/plant, leaf area index (LAI), leaf chlorophyll content, number of pods/plant, dry weight of leaves, stem and branches, pods/plant and total dry weight/plant.
Statistical analysis of the data obtained from each trail was subjected to the analysis of variance of split plot design as described by Snedecor and Cochran (1967). Combined analysis of variance for the two seasons was taken, using the appropriate analysis of variance according to Leclery et al. (1966). Treatments means were compared using the least significant difference (LSD) test developed by Waller and Duncan (1969) at $0.5 \%$ level. Generally, the interaction between the two studied factors (cvs and $\mathrm{P}$ with and without biofertilizations) on the growth characters in different growth stages did not reach the $0.5 \%$ level of significance; consequently the data for these interactions were excluded.

\section{RESULTS AND DISCUSSION}

Tables (2, 3, 4 and 5) show the effect of phosphorus fertilization with and without bio fertilizers phosphorine or microbine on vegetative growth characteristics of two peanut varieties.

It is clearly evident from the data presented in Table (2) that over phosphorus and bio fertilization, Gereogry cv surpassed significantly Giza 6 in plant height, leaf chlorophyll content, number and dry weight of pods/plant and total dry weight of plant. While, Giza6 surpassed significantly Gereogry in leaf area/plant, LAI, dry weight of leaves and dry weight of stem and branches. That held true at different stages of growth i.e. 70,85 , and 100 days from sowing. Some investigators found varietal differences between the two studied cvs Giza-6 and Gereogry in different vegetative growth characters (Yasein, 2005 and Mohamed, 2010).

Also, over varieties, the data illustrated in Tables (3, 4, and 5) show that increasing phosphorus levels from 0 to the highest level $31 \mathrm{~kg} \mathrm{P}_{2} \mathrm{O}_{5} /$ fad increased significantly almost the forementioned vegetative growth characteristics of peanut. The favourable effect of increasing phosphorus levels on the above mentioned traits was more pronounced when the bio fertilization phosphorine or microbin was applied and the two bio fertilizers did not differ significantly in this respect. This might be attributed to that fertilization with any of the two bio fertilizers converted the unavailable phosphorus as tricalcium phosphate to the available phosphorus. That led to enhance the efficiency of peanut plants in utilizing phosphorus fertilizer, which in turn had favourable effects on peanut growth. These results concerning the mentioned beneficial effect of $P$ fertilizer with or without bio fertilization on peanut growth are in harmony with those obtained by several investigators (Kabesh et al., 1987; Bahr, 1997; Detroja et al., 1997; Abdel-Wahab et al., 1999; El-Dsouky and Attia, 1999; Borse et al., 2002; More et al., 2002; ElHabbasha et al., 2005 and Mirvat et al., 2006).

The interaction between peanut varieties and phosphorus fertilizers with or without any of the two studied bio fertilizers phosphorine and microbin did not exert significant effect on different vegetative characteristics of peanut as well as leaf chlorophyll content, which means that each factor act independently. Therefore the data of the interaction were excluded. 
Table (2): Effect of varieties on some growth characters of peanut plants at 70, 85 and 100 days after sowing combined averages of the two growing seasons 2012 and 2013.

\begin{tabular}{|c|c|c|c|c|c|c|c|c|c|}
\hline Growth stage & 70 day & 85 day & 100 day & 70 day & 85 day & 100 day & 70 day & 85 day & 100 day \\
\hline $\begin{array}{l}\text { Characters } \\
\text { varieties }\end{array}$ & \multicolumn{3}{|c|}{ Plant height (cm) } & \multicolumn{3}{|c|}{ Leaf area/plant $\left(\mathrm{cm}^{2}\right)$} & \multicolumn{3}{|c|}{ Leaf area index (LAI) } \\
\hline Giza-6 & $40.2 \mathrm{~b}$ & $48.3 b$ & $53.8 \mathrm{~b}$ & $2531.6 \mathrm{a}$ & $2983.7 \mathrm{a}$ & $3458.8 \mathrm{a}$ & $4.22 \mathrm{a}$ & $4.97 \mathrm{a}$ & $5.76 \mathrm{a}$ \\
\hline Gereogry & $44.1 \mathrm{a}$ & $53.3 \mathrm{a}$ & $58.3 \mathrm{a}$ & $2338.2 \mathrm{~b}$ & $2635.9 \mathrm{~b}$ & $3189.8 \mathrm{~b}$ & $1.95 \mathrm{~b}$ & $2.19 \mathrm{~b}$ & $2.66 \mathrm{~b}$ \\
\hline LSD at $5 \%$ & 1.2 & 1.2 & 0.9 & 24.8 & 24.7 & 22.2 & 0.04 & 0.03 & 0.03 \\
\hline $\begin{array}{l}\text { Characters } \\
\text { varieties }\end{array}$ & \multicolumn{3}{|c|}{ Leaf chlorophyll content } & \multicolumn{3}{|c|}{ Number of pods/plant } & \multicolumn{3}{|c|}{ Dry leaves/plant (gm) } \\
\hline Giza-6 & $45.29 \mathrm{~b}$ & $45.30 \mathrm{a}$ & $47.26 \mathrm{~b}$ & $22.8 \mathrm{~b}$ & $33.9 \mathrm{a}$ & $41.4 \mathrm{~b}$ & $34.6 \mathrm{a}$ & $47.3 \mathrm{a}$ & $57.5 \mathrm{a}$ \\
\hline Gereogry & $46.88 \mathrm{a}$ & $46.07 \mathrm{a}$ & $49.28 \mathrm{a}$ & $34.4 \mathrm{a}$ & $47.3 \mathrm{a}$ & $63.9 \mathrm{a}$ & $30.9 \mathrm{~b}$ & $44.9 \mathrm{~b}$ & $53.7 \mathrm{~b}$ \\
\hline LSD at $5 \%$ & 1.38 & ns & 0.59 & 0.6 & 1.2 & 1.1 & 0.7 & 1.3 & 1.4 \\
\hline $\begin{array}{l}\text { Characters } \\
\text { varieties }\end{array}$ & \multicolumn{3}{|c|}{$\begin{array}{l}\text { Dry weight of stem and } \\
\text { branches per plant (gm) }\end{array}$} & \multicolumn{3}{|c|}{ Dry weight of pods/plant (gm) } & \multicolumn{3}{|c|}{ Total dry weight /plant (gm) } \\
\hline Giza-6 & $28.9 \mathrm{a}$ & $41.3 \mathrm{a}$ & $50.2 \mathrm{a}$ & $19.2 \mathrm{~b}$ & 41.2 & $41.2 \mathrm{~b}$ & $82.6 \mathrm{a}$ & $121.1 \mathrm{~b}$ & $148.9 \mathrm{~b}$ \\
\hline Gereogry & $26.3 b$ & $39.9 b$ & $47.3 b$ & $26.9 \mathrm{a}$ & 43.6 & $55.5 \mathrm{a}$ & $84.3 \mathrm{a}$ & 126.9 a & $156.5 \mathrm{a}$ \\
\hline LSD at $5 \%$ & 0.8 & 0.9 & 0.8 & 1.1 & 1.2 & 1.2 & ns & 1.7 & 1.6 \\
\hline
\end{tabular}

Table (3): Effect of phosphorus fertilization levels and biofertilization with phosphorein or microbein on some growth characters of peanut plants at 70, 85 and 100 days after sowing, combined averages of the two growing seasons 2012 and 2013.

\begin{tabular}{|c|c|c|c|c|c|c|c|c|c|c|}
\hline \multirow{2}{*}{\multicolumn{2}{|c|}{$\begin{array}{l}\text { Characters } \\
\text { Fertilization }\end{array}$}} & \multicolumn{3}{|c|}{ Plant height (cm) } & \multicolumn{3}{|c|}{ Leaf area/plant $\left(\mathrm{cm}^{2}\right)$} & \multicolumn{3}{|c|}{ Leaf area index/plant } \\
\hline & & $\begin{array}{c}70 \\
\text { day }\end{array}$ & $\begin{array}{r}85 \\
\text { day }\end{array}$ & $\begin{array}{l}100 \\
\text { day }\end{array}$ & $\begin{array}{c}70 \\
\text { day }\end{array}$ & $\begin{array}{c}85 \\
\text { day } \\
\end{array}$ & $\begin{array}{l}\text { 100 } \\
\text { day }\end{array}$ & $\begin{array}{c}70 \\
\text { day }\end{array}$ & $\begin{array}{r}85 \\
\text { day } \\
\end{array}$ & $\begin{array}{l}100 \\
\text { day }\end{array}$ \\
\hline \multirow{4}{*}{$\begin{array}{c}\mathrm{P}_{2} \mathrm{O}_{5} \mathrm{~kg} / \mathrm{fad} \\
\text { without } \\
\text { biofertilizer }\end{array}$} & $\mathbf{0}$ & 34.2 & 39.1 & 46.5 & 2082.6 & 2506.9 & 2903.3 & 2.62 & 3.18 & 3.67 \\
\hline & 15.5 & 37.9 & 46.7 & 50.3 & 2170.4 & 2583.2 & 3074.3 & 2.75 & 3.29 & 3.90 \\
\hline & 23.25 & 41.3 & 50.2 & 53.7 & 2395.4 & 2774.0 & 3273.1 & 3.04 & 3.54 & 4.15 \\
\hline & 31.0 & 43.7 & 51.6 & 56.9 & 2533.2 & 2861.5 & 3360.7 & 3.22 & 3.67 & 4.25 \\
\hline \multirow{4}{*}{$\begin{array}{c}\mathrm{P}_{2} \mathrm{O}_{5} \mathrm{~kg} / \mathrm{fad} \\
\text { with } \\
\text { phosphoreine }\end{array}$} & $\mathbf{0}$ & 38.4 & 44.9 & 50.5 & 2336.8 & 2745.7 & 3269.8 & 2.92 & 3.46 & 4.13 \\
\hline & 15.5 & 41.3 & 50.7 & 56.9 & 2384.4 & 2787.3 & 3369.4 & 3.01 & 3.54 & 4.28 \\
\hline & 23.25 & 45.4 & 56.1 & 59.9 & 2592.3 & 2936.4 & 3495.2 & 3.27 & 3.74 & 4.43 \\
\hline & 31.0 & 47.5 & 56.4 & 62.3 & 2835.6 & 3165.6 & 3591.4 & 3.62 & 4.08 & 4.54 \\
\hline \multirow{4}{*}{$\begin{array}{c}\mathrm{P}_{2} \mathrm{O}_{5} \mathrm{~kg} / \mathrm{fad} \\
\text { with } \\
\text { microbien }\end{array}$} & $\mathbf{0}$ & 39.2 & 46.6 & 52.4 & 2256.1 & 2650.0 & 3258.9 & 2.85 & 3.36 & 4.14 \\
\hline & 15.5 & 43.9 & 53.1 & 58.3 & 2323.2 & 2720.9 & 3317.9 & 2.94 & 3.47 & 4.20 \\
\hline & 23.25 & 44.5 & 56.2 & 62.3 & 2549.8 & 2893.9 & 3465.1 & 3.23 & 3.70 & 4.39 \\
\hline & 31.0 & 48.7 & 58.2 & 62.3 & 2758.9 & 3091.7 & 3512.3 & 3.53 & 3.99 & 4.46 \\
\hline LSD at $5 \%$ & & 1.9 & 2.4 & 2.9 & 79.5 & 71.2 & 55.3 & 0.10 & 0.09 & 0.08 \\
\hline
\end{tabular}


Table (4): Effect of phosphorus fertilization levels and biofertilization with phosphorein or microbein on some growth characters of peanut plants at 70, 85 and 100 days after sowing, combined averages of the two growing seasons 2012 and 2013.

\begin{tabular}{ccccccccccc}
\hline \multirow{2}{*}{$\begin{array}{c}\text { Characters } \\
\text { Fertilization }\end{array}$} & \multicolumn{2}{c}{$\begin{array}{c}\text { Leaf chlorophyll content } \\
\text { (LCC) }\end{array}$} & \multicolumn{2}{c}{ Number of pods/plant } & \multicolumn{3}{c}{ Dry leaves/plant } \\
\cline { 2 - 10 } (g)
\end{tabular}

Table (5): Effect of phosphorus fertilization levels and biofertilization with phosphorein or microbein on some growth characters of peanut plants at 70,85 and 100 days after sowing, combined averages of the two growing seasons 2012 and 2013.

\begin{tabular}{|c|c|c|c|c|c|c|c|c|c|c|}
\hline \multirow{2}{*}{\multicolumn{2}{|c|}{$\begin{array}{l}\text { Characters } \\
\text { Fertilization }\end{array}$}} & \multicolumn{3}{|c|}{$\begin{array}{c}\text { Dry stem and } \\
\text { branches/plant (gm) }\end{array}$} & \multicolumn{3}{|c|}{$\begin{array}{c}\text { Dry weight of pods/plant } \\
\text { (gm) }\end{array}$} & \multicolumn{3}{|c|}{$\begin{array}{l}\text { Dry weight of /plant } \\
\text { (gm) }\end{array}$} \\
\hline & & $\begin{array}{c}70 \\
\text { day }\end{array}$ & $\begin{array}{c}85 \\
\text { day }\end{array}$ & $\begin{array}{l}100 \\
\text { day }\end{array}$ & $\begin{array}{c}70 \\
\text { day }\end{array}$ & $\begin{array}{c}85 \\
\text { day }\end{array}$ & $\begin{array}{l}100 \\
\text { day }\end{array}$ & $\begin{array}{c}70 \\
\text { day }\end{array}$ & $\begin{array}{r}85 \\
\text { day }\end{array}$ & $\begin{array}{l}100 \\
\text { day }\end{array}$ \\
\hline \multirow{4}{*}{$\begin{array}{c}\mathrm{P}_{2} \mathrm{O}_{5} \mathrm{~kg} / \mathrm{fad} \\
\text { without } \\
\text { biofertilizer }\end{array}$} & $\mathbf{0}$ & 18.1 & 28.0 & 34.2 & 17.9 & 32.4 & 41.8 & 57.7 & 92.6 & 114.6 \\
\hline & 15.5 & 21.0 & 33.3 & 42.7 & 19.3 & 34.7 & 44.1 & 67.1 & 104.6 & 135.9 \\
\hline & 23.25 & 26.7 & 39.8 & 48.2 & 21.3 & 36.4 & 46.4 & 81.1 & 121.8 & 149.8 \\
\hline & 31.0 & 32.3 & 46.4 & 54.7 & 23.3 & 38.9 & 47.9 & 94.2 & 134.8 & 160.9 \\
\hline \multirow{4}{*}{$\begin{array}{c}\mathrm{P}_{2} \mathrm{O}_{5} \mathrm{~kg} / \mathrm{fad} \\
\text { with } \\
\text { phosphoreine }\end{array}$} & $\mathbf{0}$ & 21.8 & 35.2 & 42.5 & 22.0 & 38.4 & 48.8 & 70.6 & 115.3 & 140.9 \\
\hline & 15.5 & 26.5 & 38.5 & 49.5 & 22.8 & 38.9 & 49.0 & 81.0 & 120.5 & 154.1 \\
\hline & 23.25 & 31.4 & 44.7 & 56.3 & 26.6 & 41.8 & 52.7 & 94.9 & 137.9 & 172.4 \\
\hline & 31.0 & 37.1 & 53.8 & 59.0 & 28.8 & 42.7 & 52.7 & 107.8 & 155.4 & 180.4 \\
\hline \multirow{4}{*}{$\begin{array}{c}\mathrm{P}_{2} \mathrm{O}_{5} \mathrm{~kg} / \mathrm{fad} \\
\text { with } \\
\text { microbien }\end{array}$} & $\mathbf{0}$ & 22.6 & 31.7 & 41.8 & 21.0 & 36.8 & 46.8 & 70.4 & 105.5 & 136.5 \\
\hline & 15.5 & 27.7 & 36.2 & 45.2 & 22.0 & 37.3 & 47.9 & 80.8 & 115.5 & 146.4 \\
\hline & 23.25 & 29.5 & 45.7 & 54.6 & 25.3 & 41.8 & 51.2 & 92.1 & 138.8 & 167.3 \\
\hline & 31.0 & 36.5 & 48.8 & 57.2 & 26.3 & 41.3 & 50.7 & 103.6 & 145.5 & 172.5 \\
\hline \multicolumn{2}{|l|}{ LSD at $5 \%$} & 2.0 & 1.9 & 2.2 & 2.7 & 2.9 & 3.8 & 4.4 & 4.4 & 5.8 \\
\hline
\end{tabular}




\section{REFERENCES}

Abdel-Wahab, A. M., G. M. Yakout, E. A. Ali and M. H. Greish (1999). Response of soybean crop to phosphatic fertilization, organic manuring and bio-fertilization under new reclaimed sandy soil conditions. Egypt. J. Appl. Sci., 14(8): 125-138.

Albert, E. (1978). Pot experiments for determining favourable NPK and PK ratio to be applied to spring wheat and red clover. Acker und Pflanzenbau, 22(4): 241- 251.

Bahr, A. B. (1997). Response of chickpea crop to some fertilization treatments. Ph. D. Thesis, Fac. Agric., Suez Canal Univ, Egypt, 173 p.

Borse, N. S., L. K. Patel, Y. G. Patil, P. K. Rathod and B. M. Kamble (2002). Integrated nutrient management in summer groundnut. Advances in Plant Sci., 21(1):329-331.

Detroja, K. S., D. D. Malavia, B. B. Kaneria, V. D. Khanapraand and R. K. Patel (1997). Effect of phosphatic fertilizer, phosphobacteria and seed size on plant stand, growth and yield of summer groundnut (Arachis hypogaea). Indian J. Agron., 42(3): 495-497.

El-Dsouky, M. M. and K. K. Attia (1999). Effect of inoculation with phosphate solubilizing bacteria, organic manuring and phosphate fertilization on peanut grown on sandy calcareous soil. Assiut J. Agri. Sci., 30(5): 177-187.

El-Habbasha, S. F., A. A. Kandil, N. S. Abu-Hagaza, A. K. A. El-Haleem, M. A. Khalafallah and T. G. Behairy (2005). Effect of phosphorus levels and some bio-fertilizers on dry matter, yield and yield attributes of groundnut. Bull. Fac. Agric., Cairo Univ., 56(2): 237-252.

Hafiz, S. I. (2007). Influence of bio and mineral phosphatic fertilization and spraying with micronutrients on peanut crop in newly reclaimed sandy soils. Egypt. J. Appl. Sci., 22(2A): 169-187.

Jackson, M. L. (1976). Soil chemical analysis. Prentic Hall Private Itd., New York, USA., pp. 498.

Kabesh, M.O., M. S. M. Saber and T. G. Behairy. (1987). Utilization of biofertilizers in field crop production. 1- Effect of the increasing rates of phosphatic fertilizer with and without biofertilization on growth and yield of soybean plants in pot experiments. Egypt. J. Agron., 12(12): $123-130$.

Leclery, E. L., W. H. Leonard and A. G. Clark (1966). Field plot technique. Brugross Publishing CoMinneopolis, Minnesota, USA.

Madny, A. M. (1998). Growth analysis and yield response of certain peanut cultivars to phosphorus fertilization and micronutrients. M. Sc. Thesis, Fac. Agric., Ain Shams Univ.,129 p.

Marschner, H. (1986). Mineral nutrition of higher plants. Academic Press INC, USA, 674 pp.

Migawer Ekram A. and Mona A. M. Soliman (2001). Performance of two peanut cultivars and their response to NPK fertilization in newly reclaimed loamy sand soil. J. Agric Sci. Mansoura Univ., 26(11): 6653-6667.

Mirvat E. Gobarah, Magda H. Mohamed and M. M. Tawfik (2006). Effect of phosphorus fertilize and foliar spraying with zinc on growth, yield and quality of groundnut under reclaimed sandy soils. J. Appl. Sci. Res., 2(8): 491-496.

Mohamed, M. A. H. (2010). Response of some peanut varieties to potassium and foliar application with boron at the New Valley. Ph. D. Thesis, Fac. Agric., Assiut Univ., Egypt, 131p.

More, K. A., C. B. Gaikwad and D. V. Dahat (2002). Effect of N, P, Rhizobium and phosphate solubilizing bacteria on groundnut. J. Maharashtra Agric. Univ., 27(2): 202-204.

Piper, C. S. (1950). Soil and Plant Analysis. Inter. Science Publishers Inc., New York, USA., pp 368.

Russel, E. W. (1973). Soil conditions and plant growth. Language Book Society and Longman, London pp 30-37.

Snedecoer, G.W. and W.G. Cochran (1967). Statistical methods. $8^{\text {th }}$ ED., Iowa State Univ., Press, Ames, Iowa, U.S.A., pp. 593.

Waller, R. A. and D. B. Duncan (1969). Abays rule for the symmetric multiple comparisons problem. Am. Stat. Assoc. J. Dec., 1485 p.

Yasein, M. A. T. (2005). Some factors affecting yield and seed quality of peanut (Arachis hypogaea L.). M. Sc. Thesis, Fac. Agric., Zagazig Univ, $167 \mathrm{p}$. 
تأثير التسميد الحيوي في زيادة كفاءة صنفين من الفول السوداني في الاستفادة من التسميد الفوسفاتي: 1- التأثير على النمو الفول البودي

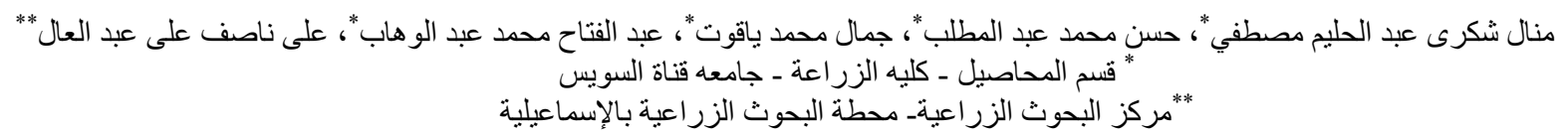

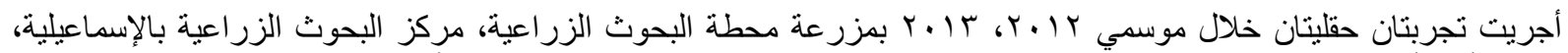

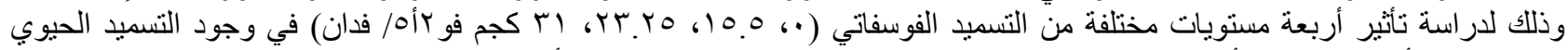

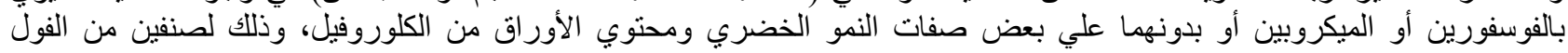
السوداني (جيزة 7ا، جريجوري).

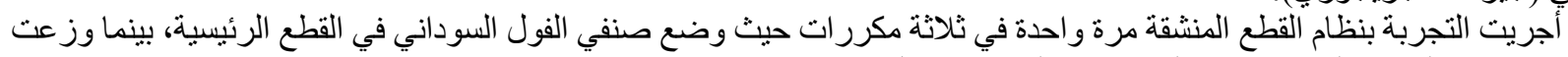

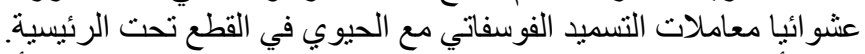

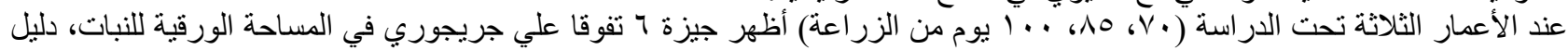

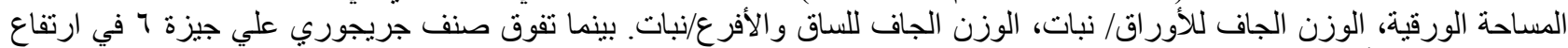

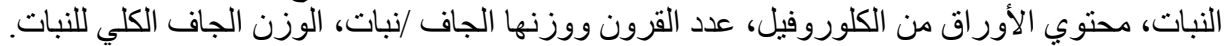

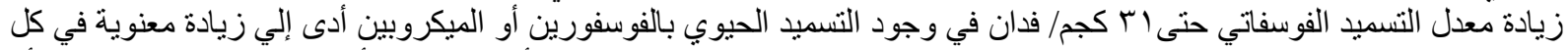

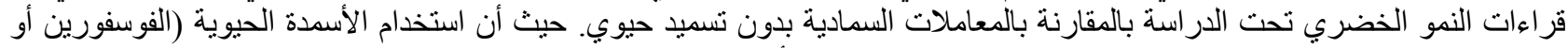

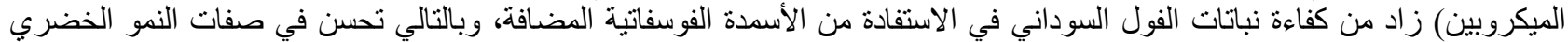

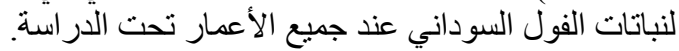

